\title{
Lost in transition: linking war, war economy and post-war crime in Sri Lanka
}

\section{Shyamika Jayasundara-Smits}

To cite this article: Shyamika Jayasundara-Smits (2018) Lost in transition: linking war, war economy and post-war crime in Sri Lanka, Third World Thematics: A TWQ Journal, 3:1, 63-79, DOI: 10.1080/23802014.2018.1473046

To link to this article: https://doi.org/10.1080/23802014.2018.1473046
(2) 2018 The Author(s). Published by Informa UK Limited, trading as Taylor \& Francis Group.

\section{8.}

Submit your article to this journal $\square$

\section{Џ Article views: 58}

View Crossmark data $\asymp$ 


\title{
Lost in transition: linking war, war economy and post-war crime in Sri Lanka
}

\author{
Shyamika Jayasundara-Smits (D) \\ International Institute of Social Studies, Erasmus University Rotterdam, The Hague, The Netherlands
}

\begin{abstract}
Scholars continue to draw attention to the link between the war economy and post-war crime. The majority of these studies are about cases of civil war that ended with peace agreements. Sri Lanka's civil war ended with a military victory for the state armed forces; thus, it can help shed new light on the above link. Situated in the war economy perspective, this article investigates the dominant types of crimes reported from post-war Sri Lanka and the mechanisms linking them with the war economy. The culture of impunity, continued militarisation and enduring corruption are identified as key mechanisms through which the war economy and post-war bodily and material crime are linked. It suggests, although the'victors' peace' achieved by state armed forces was able to successfully dismantle the extra-legal war economy run by the Liberation Tigers of Tamil Eelam, it was responsible for promoting criminality in the post-war period. Overall, this points to the urgency of breaking away from legacies of the state war economy in the post-war period, before introducing programs of longer term political and economic reform.
\end{abstract}

ARTICLE HISTORY

Received 15 June 2017

Accepted 25 April 2018

\section{KEYWORDS}

Civil war

war economy

post-war crime

Sri lanka

\section{Introduction}

The literature on civil war termination and post-war peacebuilding draws attention to interconnections and continuities between the war economy and post-war crime. They are mainly explained through a rational choice approach to conflict. Often, these studies highlight the role of greed, the resource curse, production of illicit goods, warlords and competition for the monopoly of power and violence by multiple sovereigns as drivers of violent conflicts. ${ }^{1}$ Breaking this link has been found to be important for realising positive peace. ${ }^{2}$ However, not all civil wars share the same characteristics in terms of their causes and the dynamics, during and after the war. ${ }^{3}$ The dynamics in post-war Sri Lanka are quite different from the wars that ended in the post-Cold War period with a peace agreement often facilitated by external intervention. Instead, the dynamics in post-war Sri Lanka are largely set by the military victory by the state armed forces. This allowed the state not only to defeat the Liberation Tigers of Tamil Eelam (LTTE) but also to fully reclaim a monopoly of 'legitimate 
violence.' ${ }^{4}$ Sri Lanka thus presents an opportunity to understand different manifestations of the link between the war economy and post-war crime, in a context of victors' peace. ${ }^{5}$

This article investigates the mechanisms and the relationship between the Sri Lankan war economy and dominant types of post-war crime in Sri Lanka. This article primarily relies on secondary data, including academic literature, newspaper articles, official crime data and policy documents and national and international reports compiled by civil society organisations. The official data related to war, peace and development are all highly contested. Unreliability and manipulation of data are serious issues particularly in societies that have experienced conflict and the war-to-peace transition, like Sri Lanka. ${ }^{6}$ For instance, the number of war deaths remains subject to controversy. ${ }^{7}$ So do the rosy pictures painted by state authorities about the country's economic performance during and after the war. MacGinty described the latter as the 'state's role in cooking the books'. As observed by UNODC's 9 Global Study on Homicides, Sri Lanka also suffers from incomplete data and non-availability of baseline data on homicides committed during the pre-war period. This makes it difficult to compare and contrast pre-war, war and post-war statistics. Given these limitations, author triangulated official data with limited primary data collected in Colombo at the end of April and mid-November in 2017. They were collected through informal discussions held with members of civil society organisations based in Colombo, a senior Member of Parliament (MP) representing Jaffna District and a senior police officer attached to the South Colombo Police Division.

The rest of this article is organised as follows. First, it offers a brief introduction to the legacies of the war. Next, key aspects of the war economy are presented. In the following section, major developments in post-war crime are analysed by looking at two dominant types of grave crimes (bodily and material) and the main mechanisms through which these crimes are linked with the war economy. The final section summarises these interactions and pleads for tailored strategies to reform the state and the polity.

\section{The end of war}

In May 2009, after nearly three decades of fighting, the civil war between the state armed forces (backed by some of the Sinhalese Buddhist majority) and the LTTE (backed by some of the Sri Lankan Tamil minority) came to an end. It was declared a military victory for the state armed forces. The way in which the war ended rekindled a 'give war a chance' thesis, not only in Sri Lanka but elsewhere in the world. ${ }^{10}$ It also debunked speculations by military and academic pundits that war could only end with a peace agreement. Against a background of 'peace fatigue', after repeated failed peace negotiations in a fractured political system, ${ }^{11}$ the government going for an all-war strategy was not a complete surprise. Also, as expected, military victory came at a huge cost in lives; the number of casualties in the war has been estimated at around 100,000,12 including at least 40,000 civilian deaths during the last few months of the war alone. ${ }^{13}$ On the economic front, the civil war affected Sri Lanka's production and exports, as well as the foreign direct investment (FDI) inflows. It also lowered the country's long-term growth rate. The direct and indirect economic costs of the war were mainly borne by the government. Especially, costs related to the damages to vital physical and social infrastructure are significant. The total costs borne by the government were estimated at 1.7 times the GDP of Sri Lanka in $1996 .{ }^{14}$ 
The end of the war has been marked by several other problematic legacies. Whilst the international community initially praised President Rajapaksa's government for ending the war, the way the final phase of the war was conducted was heavily criticised. This was followed by repeated calls for an international war crime investigation ${ }^{15}$ and probing into critical incidents of human rights violations during the last months of the war. ${ }^{16}$ Draconian laws, like the emergency laws and the Prevention of Terrorism Act, ${ }^{17}$ are accused of protecting the armed forces from legal prosecution for these crimes. Post-war Sri Lanka also saw an increase in the number of grave crimes recorded. ${ }^{18}$ This increase parallels trends reported from other cases of civil war ending, from El Salvador and Guatemala to the Balkans and Colombia. ${ }^{19}$ Homicide ${ }^{20}$ is a key type of grave crime often reported as increasing in these cases but this was not the case in Sri Lanka. According to the UNODC database, the rate of intentional homicides per 100,000 people fell dramatically in the post-war period from 10.16 during wartime to just 2.79 in 2013. However, as UNODC cautions, the decreasing number of homicides might be due to overlapping records of deaths resulting from intentional homicide and civilian casualties attributed to the conflict during the active years of war.

From the perspective of the 'new war' framework, ${ }^{21}$ persistent institutional weaknesses, illicit economies, criminal groups and availability of lootable natural resources are key factors encouraging criminality in the post-war contexts. As studies on Sri Lanka show, post-war crime and violence might be linked with mechanisms including militarisation, low institutional capacity, corruption, youth unemployment or circulation of weapons, either alone or in combination. ${ }^{22}$ As a follow-up to previous works, and owing to the dynamics set by the 'victors' peace' in Sri Lanka, this article is framed within the classical state-based war economy perspective to further investigate these links and mechanisms. ${ }^{23}$

\section{Sri Lanka's war economy ${ }^{24}$}

The war economy in Sri Lanka can be divided into two parts: the state-based war economy controlled by the government of Sri Lanka (GOSL), and the extra-legal war economy, run by the LTTE. ${ }^{25}$ This distinction is analytical rather than empirical. It highlights the key actors who in their main spheres of operation in real life became embedded in one or the other war economy. Both parts of the war economy were aimed at fulfilling the military priority of defeating the enemy. Naturally, the LTTE was the prime target of the state-controlled war economy and vice versa. The state-controlled war economy was sustained by various Sinhalese majority backed governments, which assumed state power from $1983^{26}$. The state's dedicated efforts to mobilise and allocate valuable resources for winning the war happened in parallel to periodic investments made in pursuing peace talks with the enemy (usually more dependent on donor financial support). ${ }^{27}$ As a result, military spending gradually grew to constitute a significant portion of the state's total spending. Much of this was dedicated to bearing the cost of the growing armed forces: in 1985, the number of military service personnel was estimated at 21,600 . In 2014 , this climbed to more than ten times that, an estimated 223,100. In the same period, Sri Lanka's military expenditure grew in real terms by $29 \% .^{28}$

Thus, although the increase in the GOSL armed forces directly fulfils military and combat functions, it also has political and economic expediency. ${ }^{29}$ The additional employment opportunities the military offers to the country's young Sinhalese has helped Sinhalese political regimes' social power base in society. ${ }^{30}$ The majority of the front-line military 
positions are filled by the poorer segments of Sinhalese youth, excluded from other, more lucrative white-collar government jobs. As Venugopal's research showed, ${ }^{31}$ employment in the military absorbed more than half of young Sinhala men from four poor districts: Ampara, Trincomalee, Polonnaruwa and Moneragala. Since the end of the war, in a fragile political system and an ailing economy, maintaining this massive number of military cadres has become more than necessary. Thus, both post-war governments have devoted a significant portion of the country's national income to the military budget (in 2016, the military budget was approximately US\$289,160,000)..$^{32}$ The increase can be seen for instance, in the difference between the 2015 defence appropriation (US\$ 2.22 billion) and its military spending in 2016, an estimated US\$2.89 billion. $^{33}$

A large portion of the military budget has been used to import weapons. ${ }^{34}$ Unlike countries at war that are also domestic arms producers, Sri Lanka's war did not give a positive boost to its economy. ${ }^{35}$ As a result, a significant portion of the defence budget was met by imposing various war-specific tax schemes, like the 'Defence Levy', 'Save the Nation Levy' and 'Nation Building Levy'. ${ }^{6}$ The 'Defence Levy' was introduced in 1992, then renamed as the 'National Security Levy'. This scheme continued until 1997 and was paid by any person who carried out business, whether manufacturing, importing or providing a service. The 'Save the Nation Levy' was imposed on any working person except those in the national police, security and military forces. It was to be paid on a quarterly basis and taxed citizens with an annual income over LKR 45,000 at $2 \%$ of their total income, and those who earned over LKR 90,000 at $3 \%$ of their total income. In the first half of the year 2000, the National Security Levy helped increase government's earnings by $8 \%$. It was also imposed on the service sector, initially at $5.5 \%$ and subsequently increased to $6.5 \%$. Alongside this, it is plausible to argue that the prolonged supply of humanitarian assistance to Sri Lanka by external actors (US\$ 74.3 million as of $2013^{37}$ ) provided an additional cushion for the government, allowing it to spend more on defence.

Furthermore, corruption in the defence sector by the political and military elites is believed to have contributed to the conception of a parallel-shadow economy. Corruption in the defence sector is difficult to uncover, partly due to the systematic silencing of critical journalists and civil society members. ${ }^{38}$ However, there is evidence to suggest that large-scale corruption took place in the defence sector during the war. One prominent example is the uninvestigated scandal of the purchase of MiG-27 aircraft from Ukraine. ${ }^{39}$

In addition to high-level corruption, instances of petty corruption in the defence and security sectors have been reported. They range from members of the defence forces and police receiving bribes from suspected LTTE members to protect them from imprisonment, and bribes to buy support to strengthen military forces' positions in the north and the east. One example is the monetarily significant deal alleged to have been struck in 2004 by the military and the ruling political regime with the breakaway LTTE group led by Colonel Karuna. ${ }^{40}$ There are many other examples of corruption linked to the defence establishment. ${ }^{41}$

\section{LTTE and the extra-legal war economy 42}

Creating a separate state was LTTE's main goal. Therefore, additionally to its military activities, LTTE also heavily invested in forming a sophisticated administrative apparatus. This dual strategy allowed the organisation to act as a quasi-state in the north and the east. ${ }^{42}$ Over 
the years, the LTTE has developed a parallel economy of its own, operating outside of the national and the international legal and regulatory frameworks. One of the main modalities of operation was through sophisticated forms of extra-legal transnational networks. As alleged by the former Sri Lankan army commander, General Rohan Daluwatte, the LTTE sustained its de facto rule in the north and some parts in the east by looting the humanitarian supplies sent by the government to the war-affected areas. These supplies include medical supplies, food and other essentials. ${ }^{43}$ Later, the LTTE-run war economy was implicated in illegal shipping operations that spanned from South India to other Asian countries and thereafter to Eastern Europe and Africa. Prior to 2005, the organisation itself owned 20 vessels approximately and a considerable number of trawlers. ${ }^{44}$ Among other related activities, the establishment of a number of boatyard companies based in East Asia (Indonesia and the Philippines) has been noted. These companies were allegedly used for transporting arms and ammunition under the pretext of cargo deliveries. Sea piracy also brought revenues to the LTTE, posing a considerable threat to the maritime security in the region. ${ }^{45}$ The LTTE is also alleged to have engaged in arms and ammunition smuggling from the Far East and Eastern European countries. The bulk of its military hardware was purchased from North Korea with some from Ukraine and Bulgaria. It also developed a parallel tax regime by introducing a range of direct and indirect taxes in the LTTE-controlled areas and in some territories held by the Sri Lankan government. ${ }^{46}$ At some point, the Tamil public servants were even asked to contribute a certain percentage of their monthly salary as income tax. Manufacturers and service providers were taxed a percentage of their monthly income. Farmers and those involved in fishing were pressured to contribute a share of their output either in cash or kind. By maximising the opportunities opened up during the intermitted brief phases of ceasefires, the organisation also raised revenues through indirect taxes in the form of customs fees on goods brought into the LTTE-controlled territory. Other sources of income included a vehicle registration tax in the LTTE-controlled areas and a tax on property transactions in Jaffna.

By 2001, the number of Tamils living abroad was estimated at $600,000-800,000$. Due to the war, the majority of Sri Lankan Tamils found refuge in Western Europe, India, Australia and North America. ${ }^{47}$ According to a report published by the Canadian Security Intelligence Services, members of the Tamil diaspora living in Switzerland, Canada, Australia, the United Kingdom, the United States and the Scandinavian countries have been funding the LTTE financially. ${ }^{48}$ According to the US State Department, the LTTE exploited the Tamil diaspora to raise funds and supplies. ${ }^{49}$ Propaganda, finance and logistics were the main forms of contribution to the LTTE's war economy from Tamils living abroad. Among the diaspora, some were willingly contributors whereas others were coerced. Approximately $80 \%$ of the LTTE's US\$ 82 million annual budget was generated from diaspora contributions (and revenues generated from international trade, enterprise and investments). ${ }^{50}$ In the late $1990 \mathrm{~s}$, the amount of money sent from the Canadian diaspora alone was estimated at between $C \$$ 1 million and more than C\$12 million a year. In 2005 and 2006, the LTTE used various methods and channels to increase its efforts to raise money for a'final war'; these included doorto-door collections by overseas members of the LTTE and LTTE-linked organisations. They also devised more targeted methods, such as approaching wealthy businesses and professionals, from whom the organisation demanded significant sums of money. In Canada, ordinary families were typically pressured to give between $C \$ 2500$ and $C \$ 5000$, whereas some wealthy businesses were pressured to give $C \$ 100,000$. 
On the home front, the LTTE also put pressure on overseas Tamils visiting their relatives in Sri Lanka to contribute. The assessed 'rate' was often $C \$ 1, £ 1$, or $€ 1$ per day for the length of time each individual has lived in the West. Such visitors were not allowed to leave the country until they produced the requested amount; in some cases, the LTTE also confiscated their passports until the money was paid. ${ }^{51}$ Zunzer noted that contradictory to some reports, not all the funds generated by the Tamil Rehabilitation Organisation (TRO) - a frontline LTTE-related humanitarian entity formed by the Tamil diaspora - were used to support military activities. The funds generated by the TRO were mainly used for development work and for paying the overheads to sustain the embryonic institutional structures of the quasi-Tamil state in the north and east of the country. ${ }^{52}$

Following the breakdown of the 2002 ceasefire, the LTTE also stepped up its recruitment drive. By this time the organisation had approximately 30,000 personnel, including both voluntary and involuntary recruits. LTTE recruits included a large number of civilians who had served in the Illapaddei force, an auxiliary force reserve on a LKR 7000 monthly salary, used for both for defensive and offensive operations. In addition, child soldiers constituted a significant number of the LTTE cadres. This is especially noted in the LTTE's eastern faction led by Karuna. ${ }^{53}$ Towards the end of 2007, a total of 6,000 children was reported to have joined, although the actual number of child soldiers is believed to be much higher. ${ }^{54}$ Similar to the government's military recruits, the LTTE recruits also had functions other than strategic military combat. In particular, they had important legitimating functions in LTTE-controlled areas. ${ }^{55}$ LTTE 'recruitment' was not only a mechanism for exploiting the vulnerability of both individuals and groups but also a protective mechanism against the Sri Lankan state. As the war economy literature suggests, the latter proposition usually involved convincing the potential members that they would be safer inside the organisation than outside. ${ }^{56}$ Given the controversial laws and practices of the Sri Lankan state - for example the Prevention of Terrorism Act (PTA - operational since 1973) and the Code of Criminal Procedure Act (CCPA), both of which were generously applied against the Tamil youth and the suspected LTTE members (as well as for the anti-state Sinhalese youth-led political group of Janatha Vimukthi Peramuna) - it might not have required much effort for the LTTE leadership to convince Tamil youth in particular to join the organisation, sometimes even without a monetary incentive. Although many of its economic activities were coerced and quasi-voluntary, the LTTE was able to legitimise these by invoking a sense of Tamil nationalism, outside threat and enemy imagery. ${ }^{57}$

\section{Linking the war economy and post-war grave crime}

As David Keen observed, post-conflict contexts are unlikely to see a clean break from violence to consent, from theft to production, from repression to democracy, or from impunity to accountability. ${ }^{58}$ Peacebuilding also involves transforming war economies into peace economies. Thus, a successful and sustainable transition requires a nuanced understanding of the dynamics in the post-war contexts. To this end, crime-related developments and the identification of possible links of these with the war economy are crucial. ${ }^{59}$

Broadly speaking, post-war Sri Lanka is marked by the intermeshing of crimes committed during and after the war. The crimes committed during the war are mainly the alleged war crimes committed during its last phase. Many reports both locally and internationally implicate the state armed forces and LTTE equally (e.g. UN expert panel report on the direction 
of the Secretary-General, the UN High Commission for Human Rights and the locally commissioned Udalagama and Paranagama Commission report). ${ }^{60}$ So far, the United Nations has passed a number of resolutions calling for cooperation from the Sri Lankan state authorities to conduct a credible investigation into the alleged war crimes committed by both parties. ${ }^{61}$ These calls are supported by many Western governments (including the US and the EU) and the majority of the Tamil diaspora. Ironically, the former are accused of selling deadly weapons to the Sri Lankan Government during the last phase of the war. For instance, UK's arms exports were worth more than $£ 13.6$ million. ${ }^{62}$ It is not only the net value of these weapons that should deserve attention but how these arms deals by-passed the existing 1998 EU Code of Conduct on Arms Export. ${ }^{63}$ Like the localised war economy in Sri Lanka, these controversial arms sales point to the importance of the transnational scale, in which Sri Lanka's war economy was firmly embedded and found sustenance.

The official statistics show a gradual increase in grave crimes in the post-war period with minor fluctuations in some sub-categories. The increasing brutality and frequency with which they are committed are noted too. ${ }^{64}$ The trend of increasing grave crimes was first reported only in the last few years. It has alluded to various factors such as rapid economic growth, social development and changes in individual lifestyles. ${ }^{65}$ Given the unreliability of official data, it is difficult to demonstrate a significant rise in the number of grave crimes just by following the official records. In this regard, one noteworthy revelation by a senior police officer interviewed for this article is the new tendency among various police divisions to downplay and under-report grave crimes. This is mainly done to secure promotions and show better service records to access benefits related to job performance. ${ }^{66}$ To garner the fuller picture, it is also necessary to triangulate the official statistics, prevailing social discourses (both mainstream and the marginal) and primary qualitative data. The developments related to the post-war grave crime and their possible links with the war economy are barely acknowledged in local social discourses. However, researchers have begun explaining some of the mechanisms that link the war and some of the developments related to post-war grave crime. These studies are primarily situated in psychosocial, ${ }^{67}$ gender, ${ }^{68}$ criminology and media-based ${ }^{69}$ theories using primary qualitative data. As a follow up to these studies, deriving from a political-economy based analysis, a more nuanced picture of the link between the war economy and the post-war grave crime is presented below.

\section{Bodily crimes}

Bodily crime is widely reported from post-war Sri Lanka and between 2009 and 2013 the number of complaints received by the police for investigation of bodily crimes of a sexual nature alone increased by $34 \% .{ }^{70}$ Since the end of the war, many cases of abductions and disappearances have been reported from the former war zone. A person has been abducted or 'disappeared' roughly once every five days. ${ }^{71}$ Women and girls - particularly among the internally displaced people (IDP) - are the main targets of these incidents. Trafficking of women, especially widows and single mothers, and rape have been reported from the war-affected areas. As the regional patterns suggest, at least five incidents of rape have been recorded daily in the north and east of Sri Lanka since 2009. Since most cases are not even reported, the official figure could be even higher. ${ }^{72}$ As the Organisation of Women for Rights has highlighted, in the north and the east, the majority of the victims of such crimes (rape, sexual violence, torture, abduction and arbitrary detention) are allegedly connected to the 
state armed forces. The lack of domestic investigations undertaken with regard to crimes reported in the post-war period is considered a continuing crime against humanity. ${ }^{73}$

A considerable number of sexual crimes have also been reported from districts of Anuradhapura, Polonnaruwa, Kurunegala and Monaragala, which are adjacent to the former war zone. During the war, these areas played an interlocutory role connecting the war in the north with the south by serving as major recruitment hubs for the state armed forces. In these areas, and especially in Anuradhapura, brothels held sex-trafficked women and children. This, the US Department of State said, was linked to the area's role as 'a major transit point for members of the Sri Lankan armed forces heading north'. ${ }^{74}$ The former combatants from the state armed forces have been blamed for most of the bodily crimes reported from these areas. Some blame the lack of systematic psycho-social support to the military for the increasing number of bodily crimes committed by the army soldiers. ${ }^{75}$

The possibility of soldiers' involvement in or planning of these criminal activities was also suggested by De Votta. ${ }^{76}$ According to him, an estimated 35,000 state armed forces who were stationed in Jaffna (the provincial capital of the Northern Province after the end of the war) could have had a stake in these incidents. A more recent phenomenon called 'grease devil attacks' carried out by naked or semi-naked men smeared in grease sexually assaulting women has also been reported in the post-war north and in the east, suspected as the works of the armed forces. ${ }^{77}$ These local accusations also resonate with incidents of the systematic sexual abuse and rape of children reported against the Sri Lanka soldiers who served in the UN peacekeeping missions in Haiti and the Central African Republic. So far, the Sri Lankan authorities have failed to conduct any formal investigation into these incidents. ${ }^{78}$

\section{Material crimes}

A higher number of material crimes is also reported from post-war Sri Lanka. Since 2014, the share of material crime has comprised an average of $40 \%$ of all grave crimes committed. ${ }^{79}$ According to the Police Narcotic Bureau, a majority of these crimes are related to drug trafficking and drug abuse, both criminal offences under law. ${ }^{80}$ The exact increase in these crimes is difficult to pin down. Non-comparable data sets following the introduction of the new crime category (minor offences) and politicians' meddling in the reporting ${ }^{81}$ and investigation of these crimes partly explains this. However, the relatively high number of material crimes is confirmed by periodic statements issued by the law enforcement authorities. Further, as noted by the police officer interviewed for this study, material crimes such as burglary and theft involving firearms have also been linked with the widespread availability of small arms and light weapons since the end of the war and their frequent use by (ex) members of the Civil Defence Forces. This connection has also been confirmed by the senior superintendent of police, citing a recently compiled set of data collected across the island. ${ }^{82}$ Although making an absolute link between material crimes and the war economy requires systematic collection of evidence and further substantiation, there are several mechanisms at play through which the two might be connected.

In general, economic difficulties increase the number of material grave crimes. ${ }^{83}$ This raises the contrast between post-war reality and the rhetoric of the Rajapakse regime. The regime boasted of rapid economic growth during its tenure amidst the war and in the postwar period. In 2011, it even forecasted an average of $8.1 \%{ }^{84}$ economic growth. Based on its own figures, the regime saw no problem in delivering the promised peace-economic 
dividends. However, real post-war economic growth has been calculated at $2.5 \% .{ }^{85}$ It showed a gloomy economic scenario with consistently high levels of inflation $(6.22 \%$ in $2010,6.74 \%$ in $2011,7.53 \%$ in 2012 and $6.94 \%$ in 2013). This inflation only started to decrease since $2015 .{ }^{86}$

It is widely believed that the extension of the war economy into the post-war period through further militarisation and high defence expenditure siphoned out resources that would have been available to generate the promised economic dividends related to peace and to address the challenge of widening inequality. ${ }^{87}$ Even the claimed rapid economic boom (infrastructure development, improved agricultural productivity) in the north and the east in the post-war period has become a cause of concern since it came with political strings attached. These made inroads for further militarisation and securitisation of the land and the population..$^{88}$ The resources dedicated to maintaining a 450,000-strong military force (currently the ratio of military cadre to population is 1:5), in the absence of an active armed conflict or imminent threat of such, are particularly burdensome for the economy. ${ }^{89}$

Further, during the Rajapaksa regime, the military was re-deployed to perform non-military activities. It was assigned a key role in the post-war development strategy. The military was involved in large-scale property development ventures and in state-sponsored mega-infrastructure development projects (such as building roads, bridges, houses and sports stadiums). To facilitate this further, in 2012 the budget of the Defence Ministry was merged with the Urban Development Authority, yielding a combined budget of about 229.9 billion Sri Lankan Rupees. At that time, this combined budget was the largest of any government ministry. ${ }^{90}$ All these were justified by highlighting the need for continued securitisation and the need to preserve the high (4.8\% figures contested) economic growth achieved during the war. $^{91}$

The regime's new development strategy negatively affected ordinary people's lives. ${ }^{92}$ It dismantled the wartime coping economy in the north as a result of pursuing a national security state, which let the military to occupy and even forcibly annex vast amounts of fertile land in the north and east. ${ }^{93}$ The military is also accused of driving away impoverished women from their livelihood activities (i.e. small-scale subsistence farming and selling homegrown produce in informal markets). Overall, the might of the military and state patronage military received created unfair conditions and unfair competition for the women in the coping economy. ${ }^{94}$

Although up to 2015 the Rajapakse regime spent massive sums of money borrowed from Chinese banks at a commercial rate, the dividends of these large-scale investments (in the form of large-scale reconstruction and development projects) have not reached average people. ${ }^{95}$ Even allocations for essential services such as health and education have experienced a rapid decline, whilst military expenditure continues to rise. ${ }^{96}$ Meanwhile, repeating the earlier patterns following failed peace-making efforts, the promised economic dividends of peace also did not reach to the south where most of the Sinhalese live. Some blame this on the workings of the country's electoral system and on unfavourable conditions imposed by the World Bank. ${ }^{97}$ In sum, higher military spending, combined with factors like droughts, a deepening budget deficit and a high international debt to GDP ratio, has meant a looming economic crisis. These events suggest a link between the war's entrenching effects on the economy in the post-war period and the increasing number of material crimes.

Increasing unemployment levels is another mechanism that may explain the link between war economy and post-war material crime. Sri Lanka's unemployment rate was $4.4 \%$ in 2014, $4.6 \%$ in 2015 and $4.9 \%$ in $2016 .{ }^{98}$ According to national data, youth unemployment is 
currently as high as $14.2 \%$. Youth unemployment is remarkably similar in areas directly and indirectly hit by the war. For instance, the southern districts of Matara and Kegalle trail only slightly behind the directly war-affected districts of Jaffna, Killinochchi and Ampara. ${ }^{99}$ Tragically, as evident in various reports, the post-war economic woes experienced by the youth are manifested in many forms. Among these, the inclination to commit material crimes as well as bodily crimes, such as suicides, are notable. Depression and Post-Traumatic Stress Disorder (PTSD) due to financial hardships and loss of livelihoods have been identified as main causes for the majority of the youth suicides reported from the North. ${ }^{100}$

When probing material crimes, corruption also deserves scrutiny. Under Sri Lankan law, corruption is a criminal offence but it has been a persistent problem in Sri Lanka. Sri Lanka ranks as a highly corrupt country in Transparency International's Corruption Perception Index. As World Governance Indicators show, control of corruption has not improved over the last 15 years. There has been a lack of enforcement of anti-corruption legislation, often leaving powerful political elites who commit such acts unpunished. ${ }^{101}$ Political tendencies of the authoritarian style of governance, militarised state and centralisation of powers that emerged and sustained during and after the war and especially during the Rajapaksa regime, have led to enduring corruption. ${ }^{102}$ Coupled with the war-related burdens laid on the economy, corruption further reduced the capacity of the state to generate economic growth and a fair redistribution system. As recent literature shows, ${ }^{103}$ increasing criminality is one manifestation of the combined effects of inequality, mistrust and corruption. Promises to eradicate corruption (along with other measures of good governance) were the backbone of President Sirisena's election campaign. Sadly, so far the government has been unable to make any satisfactory progress. ${ }^{104}$ Neither the end of the war nor the regime change in 2015 has severed the link between structurally rooted corruption, the economy and politics. ${ }^{105}$ The continued high level of corruption in the post-war period ${ }^{106}$ not only undermines and delays economic recovery but also potentially leaves room for a relapse into violence, criminality and social conflict.

\section{Conclusion}

Despite the difficulty of obtaining data, Sri Lanka is an interesting case study for literature on the war economy and post-war crimes. Although it is nearly a decade since the war ended, the legacies of the war continue to manifest in different forms. An increase in post-war grave crime (in terms of bodily and material) is one notable form. In this background, this article examined the dominant types of crimes reported from post-war Sri Lanka and the mechanisms linking them with the war economy. Bodily crime is the most dominant type of crime reported from former war ravaged north and the east. The increased number of bodily crimes mostly reported from these areas in the immediate years after the war links with the dynamics set by a victor's peace and the impunity enjoyed by the state armed forces. This link is further established by the state's continued efforts at the post-war militarisation of the economy and society. The only favourable outcome brought by the victor's peace was the ability to delink the LTTE from Sri Lanka's post-war crime scenario. This was possible due to strong discipline inherited by the former LTTE cadres during their time in the organisation, the government's efforts to demobilise ex-LTTE members, and continued militarisation and pursuit of national security state since the end of the war. 
In the post-war period, material crime is the most dominant type of crime reported from the southern part of the country, where majority Sinhalese live. This article also identified the culture of impunity, a lack of progress in generating peace-economic dividends, and uncontrolled corruption as additional mechanisms linking the war economy and the postwar material crimes. This is further intensified by external factors such as continued droughts, the negative trade relationships developed with the West (especially the EU) and the loss of access to important concessionary development aid schemes as Sri Lanka graduated to middle-income status in 2010. However, the inner workings of these mechanisms require further investigation, through more systematic data and evidence gathering.

Overall, the developments noted related to Sri Lanka's post-war grave crime share similarities as well as differences with other post-war contexts. One notable difference is the state's role in the promotion of criminality in the guise of a victor's peace. This was especially observed during the 2009-2015 period. A country's tenuous economic base, destructive political culture (of elites and their supporters alike) and a flawed political system certainly has the ability to produce and reproduce the link between the war economy and post-war grave crime. Thus, a successful post-war transition will require tailor-made strategies targeting reforms to the moral, political and economic edifice of both the state and its polity.

\section{Disclosure statement}

No potential conflict of interest was reported by the author.

\section{Notes on contributor}

Shyamika Jayasundara-Smits is an associate researcher and adjunct lecturer with the International Institute of Social Studies (ISS) of Erasmus University Rotterdam, The Netherlands. Her current research focuses on Security Sector Reform, Civil-Military Relations and European Union Common Security and Defence Policy. She teaches in Governance and Conflict, Violent Conflict, Media and Politics of Representation, Securitisation of Development in ISS's MA in Development Studies Programme. She holds a PhD in Development Studies from ISS, Erasmus University Rotterdam, an MA in Conflict Transformation and Peacebuilding from Eastern Mennonite University, Virginia, USA and a BA in International Relations from University of Colombo, Sri Lanka.

\section{Acknowledgements}

Author would like to thank the two anonymous peer-reviewers for their critical comments and Dr. Sabine Kurtenbach and Désirée Reder for their helpful comments during various stages of writing of this article.

\section{ORCID}

Shyamika Jayasundara-Smits (iD) http://orcid.org/0000-0002-1022-269X

\section{Notes}

1. Reno, Warlord Politics and African States; Le Billon, "Diamond Wars?"; Humphreys, "Natural Resources, Conflict, and Conflict Resolution"; Pugh, Cooper and Goodhand, War Economies in a Regional Context; and Nordstrom, "Women, Economy, War." 
2. Galtung ("Violence, Peace, and Peace Research," 183) defines positive peace as absence of structural violence.

3. Goodhand, "From War Economy to Peace Economy?"; and Sedra "Security sector reform in Afghanistan."In the South Asian region, Afghanistan best demonstrates the close connections between war economy and post-war crime. It is important to note despite the ousting of the Taliban in 2001, conflict is ongoing between the Taliban and the elected government. Thus, the country does not fully present a post-war or post-conflict situation.

4. Defined as violence lawfully exercised by the state under a legitimate civilian authority, where actors conduct themselves in accordance with democratic norms and principles.

5. Understood as peace resulting from a military victory.

6. Mac Ginty, 2013, 425.

7. For different estimates see Mango, Colombo Telegraph, 14 February 2014.

8. Holt, "The Limits of Formal Metrics during Conflict and Post-conflict Transition," 9.

9. UNODC, "Global Study on Homicides 2013," 78, 104.

10. Presented by Luttwak "Give War a Chance," making a case for reconsidering a military solution to terminate civil wars and peace through force of arms.

11. The last peace process ran between 2002 and 2008. It was dominated by the international actors, led by Norway, and co-chaired by Japan, the USA and India. The heavy international involvement is attributed to the various shifts that occurred in both the global and local political economies.

12. United Nations, Report of the Secretary-General's Panel of Experts, iii.

13. ICANS, What the Women Say.

14. Arunatilake et al., The Economic Cost of the War.

15. United Nations, Report of the Secretary-General's Panel of Experts, 11, 12.

16. ICJ 2012 report on "Authority without Accountability," 13.

17. See ICJ report 2012, Authority without Accountability, 42-56 for a fuller picture of the various questionable laws introduced by the State during the war.

18. Grave crimes are crimes that are indictable. There are two main categories of grave crimes: bodily and material. Killing, adduction, rape, incest and other physical forms of harm come under bodily grave crimes. Robbery, theft, house-breaking, drug manufacturing, possession and smuggling, all constitute material grave crime.

19. As cited in Kurtenbach and Rettberg, "Understanding the Political, Economic, and Social System after War Termination," n.p.

20. Homicide is the killing of a human being due to the act or failure to act of another. There are two main types of homicides: Criminal and non-criminal. Criminal homicides include murder and manslaughter. Non-criminal homicides include killing in self-defence, a misadventure or legal (government) execution.

21. Kaldor, New and Old Wars.

22. Kurtenbach and Rettberg, "Understanding the Political, Economic, and Social System after War Termination," 1,3 .

23. This framework captures economic activities undertaken by the state to mobilise for the purpose of war, to support the military effort, to protect and defend the home territory, and especially to maintain the physical well-being, solidarity and morale of the people (Galbraith, "The Meaning of a War Economy," 5). During a relatively brief period under the Rajapakse regime, scholars such as Rajasingham-Senanayake attempted to apply the 'Milbus' framework developed by famous Pakistani scholar Ayesha Siddiqa (2007) to explain the rise of the military economy in Sri Lanka. Milbus is defined as military capital used for the personal benefit of military fraternity (1). Siddiqa's main aim was to show how business interests of the military relate to the personal enrichment of the Pakistani military and to the political ambitions of the armed forces. Application of this framework to this study is limited because Milbus does not capture the dynamics of a post-war setting. Unlike Sri Lanka's brief experience with the military economy, Milbus is drawn by analysing a long period of military's role and the interests in Pakistani's economy and conditioned by several long intermittent periods of military rule. Pakistani military elites function as a class or as a political party on their own, whereas in Sri Lanka, the military is not free from civilian rule and only functions as an aide to the flawed 
democratic system and to the civil political elites. For these reasons, I have chosen to apply Galbraith's perspective, which allows capturing not only the military economy but also other dimensions of a war economy and the subjective goals that it tries to instil in a population.

24. For an elaboration of different typologies of war economies illustrated by Afghanistan - that is, combat economy, shadow economy, and coping economy - see Goodhand, "From War Economy to Peace Economy?" 168.

25. This typology is used for organising the data based on an actor-centric approach and modelled on the typologies of economies embedded in war economy by Goodhand 2003.

26. 1983 is considered as the official beginning of the civil war.

27. Jayasundara-Smits, "Conflict, War and Peace in Sri Lanka," 3.

28. SIPRI, Military Expenditure (\% of GDP) Yearbook.

29. Venugopal, "The Politics of Market Reform at a Time of Civil War."

30. Goodhand, "Sri Lanka in 2012," 70.

31. "The Politics of Market Reform at a Time of Civil War," 73.

32. The World Bank website, calculations based on SIPRI Current Military expenditure (LCU).

33. SIPRI, Military Expenditure by Country, in Local Currency, 1988-2016.

34. According to the SIPRI database (Arms imports-SPRI trend indicator values) in arms imports reached an all-time high in 2000, featuring close to US\$300 million.

35. Goodhand, "Sri Lanka in 2012."

36. The 'nation building tax' rate of $2 \%$. As per the newest regulations, certain services such as telecommunications and electricity supplies and certain petroleum products (such as lubricants) and supplies of goods for a specified building project are exempt (KPMG Sri Lanka 2016 report, "Indirect Tax Alert," 2).

37. Global Humanitarian Assistance Report: A Development Initiative, Sri Lanka Country Profile, 2013 Key Figures. www.globalhumanitarianassistance.org/countryprofile/sri-lanka

38. Lindberg and Orujela, "Corruption and Conflict," 215.

39. http://www.sundaytimes.lk/070812/Columns/sitreport.html.

40. Vinayagamoorthi Muralitharan, widely known as Col. Karuna, was the second-in-command of the LTTE and the leader of the eastern command of the LTTE. In 2004 he defected from the LTTE and joined the government ranks. He is currently facing numerous war crimes charges committed during the war and even after.

41. Lindberg and Orujela, "Corruption and Conflict," 215.

42. Nordstrom $(2010,162)$ uses the term extra-legal to denote all economic activities that fall outside state-based definitions of legal This encompasses the informal, illicit, illegal, unrecorded and undefined.

42. Stokke, "Building the Tamil Eelam State," 1022.

43. Business Today, July 2011.

44. Ibid.

45. Ibid.

46. Stokke, "Building the Tamil Eelam State," 1034.

47. Venugopal, The Global Dimensions of Conflict in Sri Lanka, 20.

48. Chalk, Liberation Tigers of Tamil Eelam's (LTTE) International Organisation and Operations.

49. Country Reports on Terrorism 2016 - Foreign Terrorist Organisations: Liberation Tigers of Tamil Eelam (LTTE), 19 July 2017.

50. As cited in Venugopal, The Global Dimensions of Conflict in Sri Lanka, 22.

51. Human Rights Watch n.d, 2.

52. Zunzer, Diaspora Communities and Civil Conflict Transformation, 28.

53. Report by Business Today titled, "Evolution Of The LTTE And International Networking," July 2011.

54. Child Soldiers International, Global Report 2008.

55. Terpstra and Frerks, Rebel Governance and Legitimacy Civil Wars.

56. Liebenberg et al., "A Theory of War Economies," 311.

57. Terpstra and Frerks, Rebel Governance and Legitimacy Civil Wars.

58. Keen 2007, 10. 
59. Goodhand, "From War Economy to Peace Economy?"

60. Deliberations of all these reports are contained in 'Presidential Commission of Inquiry into Complaints of Abductions and Disappearances, Report on the Second Mandate of the Presidential Commission of Inquiry into Complaints of Abductions and Disappearances' (2015). http://media.wix.com/ugd/bd81c0_02a8e91c18ab47359763b405c2d9f89e.pdf.

61. De Votta, "Sri Lanka: From Turmoil to Dynasty," 139.

62. The Independent, 18 February 2013.

63. Ibid.

64. Ibid.

65. Niriella, "Thinking of new Horizon in Criminal Justice," 284.

66. As this officer noted, the current official crime statistics are also downplayed due to the introduction of a new softer crime category called 'minor offences', that is, crimes that are non-indictable.

67. YPF, Nexus between Post War Trauma and Increased Violence.

68. Guruge et al., "Intimate Partner Violence in the Post-war Context."

69. Siriwardhana, "Post War Media Behavior in Sri Lanka."

70. Report of the Leader of the Opposition's Commission on the Prevention of Violence against Women and the Girl Child noted, 2014, 22.

71. Goodhand, "Sri Lanka in 2012."

72. ICANS, What the Women Say, 3.

73. See note 15 above.

74. United States Department of State, Trafficking in Persons Report.

75. Jinadasa, "Rate of Crime and the Involvement of Army Soldiers in Post Conflict Society in Sri Lanka," 41; and Colombage, "Crime among Sri Lanka Soldiers on Rise."

76. "Sri Lanka: From Turmoil to Dynasty," 139.

77. ICG East Asia report no. 217 titled, "Sri Lanka: Women's Insecurity in the North and East," 20 December 2011, 30.

78. Hindustani Times, 4 June 2017.

79. Presentation by the Crime Intelligence Analysis Bureau of Police 2016.

80. www.police.lk/index.php/narcotic-bureau/145.

81. From the interview with the senior Police official.

82. Sunday Leader, 12 December 2012.

83. Webster and Kingston, Anti-Poverty Strategies, 10.

84. Goodhand, "Sri Lanka in 2012," 131.

85. Uyangoda, "Sri Lanka in 2009," 110.

86. Based on the Central Bank Data.

87. Nanayakkara, "Can Sri Lanka Eradicate Poverty."

88. Goodhand, "Sri Lanka in 2012," 133.

89. ICG, "The Forever War?"

90. Goodhand, "Sri Lanka in 2012," 70.

91. Wijeweera and Webb, "Military Spending and Economic Growth in Sri Lanka," 506.

92. Goodhand, "Sri Lanka in 2012," 68. Some have described this peculiar development as militarisation and even as military rule.

93. ICG, Sri Lanka's Transition to Nowhere, 18.

94. ICANS, What the Women Say, 5.

95. Wickramasinghe, "Sri Lanka in 2013," 203.

96. Selvanathan and Selvanathan, "Defence Expenditure and Economic Growth," 70.

97. Mac Ginty, "Bottom up Peace Indicators," 2015.

98. Word Bank Unemployment, total (\% of total labour force) (modelled ILO estimate). Compared to the world average (5.748 in 2016), Sri Lanka's unemployment rate seems low. This figure, however, does not include underemployment, which was $2.7 \%$ in 2015 . Underemployment is defined as when a person's employment is inadequate, in relation to specified norms or alternative employment, account being taken of his occupational skill (training and working experience).

99. Department of Census and Statistics, Ministry of National Policies and Economic Affairs 2016. 
100. Based on the analysis of official grave crime data.

101. ICG, Sri Lanka's Transition to Nowhere, GAN 2015.

102. Mampilly, "The Nexus of Militarisation and Corruption," 183.

103. Lindberg and Orjuela, "Corruption in the Aftermath of War."

104. ICG, Sri Lanka's Transition to Nowhere, II.

105. Lindberg and Orujela, "Corruption and Conflict," 205.

106. In 2016, Sri Lanka ranked 95th out of 176 in the Corruption Perception Index-Transparency International rankings.

\section{Bibliography}

AHRC. "Every 90 Minutes a Woman is Raped in Sri Lanka: Rape and Other Crimes against Women on the Increase." Colombo Telegraph, July 15, 20. https://www.colombotelegraph.com/index.php/ every-90-minutes-a-woman-is-raped-in-sri-lanka-rape-and-other-crimes-against-women-on-theincrease-ahrc/.

Arunatilake, Nisha, Sisira Jayasuriya, and Saman Kelegama. The Economic Cost of the War in Sri Lanka. Colombo: Institute of Policy Studies, 2015.

Business Today. Evolution of the LTTE and International Networking. 2011. http://www.businesstoday. Ik/article.php?article $=3481$.

Chalk, P. Liberation Tigers of Tamil Eelam's (LTTE) International Organization and Operations - A Preliminary Analysis. Commentary. A Canadian Security Intelligence Service Publication, 1999. https://fas.org/ irp/world/para/docs/com77e.htm\#N_19_.

Colombage, D. "Crime among Sri Lanka Soldiers on Rise." Al Jazeera/Qatar, 2014. Accessed September 25, 2015, from http://www.lankanewspapers.com/news/2014/6/88305_space.html.

Crime Intelligence Analysis Unit of Police. 2016. Presentation by C. S. K. Millawithanachchi. http://www. unodc.org/documents/data-and-analysis/statistics/Activities/seoul-2016-meeting/Supporting_ Capacity_Building_Sri_Lanka.pdf.

De Votta, Neil. "Sri Lanka: From Turmoil to Dynasty." Journal of Democracy 22, no. 2 (2011): 130-144. doi:10.1353/jod.2011.0019.

Department of Census and Statistics, Ministry of National Policies and Economic Affairs. Sri Lanka Labour Force Survey, Annual Bulletin, Colombo, 2016.

Galbraith, James K. “The Meaning of a War Economy." Challenge 44, no. 6 (November-December 2001): 5-12.

Galtung, Johan. “Violence, Peace, and Peace Research." Journal of Peace Research 6, no. 3 (1969): 167-191 http://www.jstor.org/stable/422690.

GAN. Sri Lanka Corruption Report. 2015. http://www.business-anti-corruption.com/country-profiles/ sri-lanka.

Global Humanitarian Assistance: A Development Initiative. Global Humanitarian Assistance: Sri Lanka Country Profile, 2015. http://www.globalhumanitarianassistance.org/countryprofile/sri-lanka/.

Goodhand, Jonathan. "From War Economy to Peace Economy? Reconstruction and State Building in Afghanistan." Journal of International Affairs 58, no. 1 (Fall 2004): 155-174.

Goodhand, Jonathan. "Frontiers and Wars: The Opium Economy in Afghanistan." Journal of Agrarian Change 5 (2005): 191-216. doi:10.1111/j.1471-0366.2005.00099.x.

Goodhand, Jonathan. "Sri Lanka in 2012: Securing the State, Enforcing the 'Peace."' Asian Survey 53, no. 1 (2012): 64-72. doi:10.1525/as.2013.53.1.64.

Guruge, S., M. Ford-Gilboe, C. Varcoe, V. Jayasuriya-Illesinghe, M. Ganesan, S. Sivayogan, et al. "Intimate Partner Violence in the Post-war Context: Women's Experiences and Community Leaders' Perceptions in the Eastern Province of Sri Lanka", PLoS ONE 12, no. 3 (2017): 1-16. doi:10.1371/ journal.pone.0174801.

Holt, Sarah. "The Limits of Formal Metrics during Conflict and Post-conflict Transition: Exploring Opportunities for Qualitative Assessment in Sri Lanka." In Alternative and Bottom-up Peace Indicators, edited by Roger Mac Ginty, 9-31. Oxon: Routledge, 2015.

Human Rights Watch. Sri Lanka: Country Summary. January 2014. https://www.hrw.org/worldreport/2014/country.../sri-lanka. 
Human Rights Watch. "Funding the 'Final War' - LTTE Intimidation and Extortion in the Tamil Diaspora." 18 , no. $1(C), x x x x-b$.

Humphreys, M. "Natural Resources, Conflict, and Conflict Resolution: Uncovering the Mechanisms." Journal of Conflict Resolution 49 (2005): 508-537.

ICANS. What the Women Say: Elusive Peace, Pervasive Violence: Sri Lankan Women's Struggle for Security and Justice. Brief 8: International Civil Society Action Network, 2013. http://www.icanpeacework. org/wp-content/uploads/2017/03/What-the-Women-Say-SriLanka-Brief-Spring-2013.pdf.

ICJ (International Commission of Jurists). Authority without Accountability: Crisis of Impunity in Sri Lanka. 2012. http://www.refworld.org/docid/50ae365b2.html.

ICG (International Crisis Group). The Forever War?: Military Control in Sri Lanka's North. March 25, 2014. http://blog.crisisgroup.org/asia/2014/03/25/the-forever-war-military-control-in-sri-lankas-north/.

ICG (International Crisis Group). Sri Lanka's Transition to Nowhere. Asia Report No. 286, May 16, 2017, Brussels.

Jayasundara-Smits, Shyamika. "Conflict, War and Peace in Sri Lanka - Politics by other means?" Paper presented at the DSA conference Rethinking Development in an Age of Scarcity and Uncertainty, York University, 2011. https://repub.eur.nl/pub/34768/.

Jayasundara-Smits, Shyamika. In Pursuit of Hegemony: Politics of State Building in Sri Lanka." PhD thesis, International Institute of Social Studies, Erasmus University Rotterdam, 2013. repub.eur.nl/ pub/40137/ThesisPDC[1].pdf.

Jinadasa, Manoj. "Rate of Crime and the Involvement of Army Soldiers in Post Conflict Society in Sri Lanka; Gender Representation in Crime and Lack of the Psycho - Social Awareness in the Army Profession." Review of Journalism and Mass Communication 3, no. 2 (2015): 41-57. doi:10.15640/ rjmc.v3n2a2.

Kaldor, Mary. New and Old Wars: Organised Violence in a Global Era. 3rd ed. Cambridge: Polity, 2012.

Keen, David. "War and Peace: What's the Difference?" International Peacekeeping 7, no. 4 (2007): 1-22.

Kurtenbach, Sabine and Angelica Rettberg. "Understanding the Political, Economic, and Social System after War Termination: War Economies and Post-war Crime: A Framework Prepared for the Second War Economies and Post-war Crime Workshop." German Institute for Global and Area Studies (GIGA), Hamburg, Germany, July 4-5, 2016.

Le Billon, P. "Diamond Wars? Conflict Diamonds and Geographies of Resource Wars" Annals of the Association of American Geographers 98 (2008): 345-372.

Liebenberg, Sybert, Richard Haines, and Geoff Harris. "A Theory of War Economies." African Security Review 24, no. 3 (2015): 307-323. doi:10.1080/10246029.2015.1075412.

Lindberg, Jonas, and Camilla Orjuela. "Corruption and Conflict: Connections and Consequences in War-torn Sri Lanka." Conflict, Security \& Development 11, no. 2 (2011): 205-233. doi:10.1080/14678 802.2011.572455.

Lindberg, Jonas, and Camilla Orjuela. "Corruption in the Aftermath of War: An Introduction." Third World Quarterly 35, no. 5 (2014): 723-736. doi:10.1080/01436597.2014.921421.

Luttwak, Edward N. “Give War a Chance." Foreign Affairs, July/August (1999).

Mac Ginty, Roger. "Introduction: The Transcripts of Peace: Public, Hidden or Non-obvious?" Journal of Intervention and Statebuilding 7, no. 4 (2013): 423-430. doi:10.1080/17502977.2012.727535.

Mac Ginty, Roger, ed. Alternative and Bottom-up Peacebuilding. Routledge, 2015.

Mampilly, Zachariah. "The Nexus of Militarization and Corruption in Post-conflict Sri Lanka."In Corruption and Post-conflict Peacebuilding: Selling the Peace?, edited by Dominik Zaum and Christine Cheng, 182-200. London: Routledge, 2012.

Nanayakkara, Wimal. "Can Sri Lanka Eradicate Poverty and Reduce Income Inequality by 2030?" Institute of Policy Studies June 3, 2016. http://www.ips.lk/talkingeconomics.

Niriella, M. A. D. S. J. S. "Thinking of new Horizon in Criminal Justice: Moving from Retributive to Restorative Justice in the Treatment of the Offenders in Sri Lanka." In Handbook of Asian Criminology, edited by Jianhong Liu, Bill Hebenton, and Susyan Jou, 283-296. New York: Springer, 2013.

Nordstrom, C. "Women, Economy, War." International Review of the Red Cross. 97, no. 877 (2010): 161-176. Pugh, M., N. Cooper, and J. Goodhand. War Economies in a Regional Context: Challenges and Transformations. Boulder, CO: Lynne Rienner, 2004.

Reno, W. Warlord Politics and African States. Boulder, CO: Lynne Rienner, 1998. 
Report of the Leader of the Opposition's Commission on the Prevention of Violence against Women and the Girl Child. 2014. http://www.childwomenmin.gov.lk/resources/30/REPORT.pdf.

Sedra, Mark. "Security Sector Reform in Afghanistan: The Slide Towards Expediency." International Peacekeeping 13, no. 1 (2006): 94-110. doi:10.1080/13533310500424868.

Selvanathan, Saroja, and E. A. Selvanathan. "Defence Expenditure and Economic Growth: A Case Study of Sri Lanka Using Causality Analysis." International Journal of Development and Conflict 4 (2014): 69-76.

Siddiqa, Ayesha. Military Inc.: Inside Pakistan's Military Economy. London: Pluto Press, 2007.

SIPRI. Military Expenditure by Country, in Local Currency, 1988-2016. https://www.sipri.org/sites/default/ files/Milex-local-currency.pdf.

SIPRI. Military Expenditure (\% of GDP) Yearbook: Armaments, Disarmament and International Security. http://data.worldbank.org/indicator/MS.MIL.XPND.GD.ZS?view=chart.

Siriwardhana, Krishan. "Post War Media Behavior in Sri Lanka." Journal of Mass Communication and Journalism 2, no. 9 (2012): 1-3. doi:10.4172/2165-7912.1000127.

Sri Lanka Tax Guide. Washington, DC and Sri Lanka: International Business Publisher USA, 2008.

Stokke, Kristian. "Building the Tamil Eelam State: Emerging State Institutions and Forms of Governance in LTTE-Controlled Areas in Sri Lanka." Third World Quarterly 27, no. 6 (2006): 1021-1040. doi:10.1080/01436590600850434.

Terpstra, N. M., and G. E. Frerks. Rebel Governance and Legitimacy Civil Wars, 1-29. ISSN: 1743-968X. 2017. The World Bank. “Unemployment, Total (\% of Total Labor Force) (Modelled ILO Estimate)." http://data. worldbank.org/indicator/SL.UEM.TOTL.ZS?end=2016\&locations=LK\&start=1991\&view=chart.

United Nations Advisory Panel. Report of the Secretary-General's Panel of Experts on Accountability in Sri Lanka. March 31, 2011. http://www.un.org/News/dh/infocus/Sri_Lanka/POE_Report_Full.pdf.

United Nations Peacebuilding Office. Peace Dividends and Beyond: Contributions of Administrative and Social Services to Peacebuilding. New York: UN, 2012.

United States Department of State. Trafficking in Persons Report - Sri Lanka. Sri Lanka, June 27, 2011. www.refworld.org/docid/4e12ee4832.html.

United States Department of State, Bureau of Diplomatic Security. "Sri Lanka 2015 Crime and Safety Report." 2015. www.osac.gov/pages.

Uyangoda, Jayadeva. "Sri Lanka in 2009: From Civil War to Political Uncertainties." Asian Survey 50, no. 1 (2010): 104-111 http://www.jstor.org/stable/10.1525/as.2010.50.1.104.

Venugopal, Rajesh. The Global Dimensions of Conflict in Sri Lanka. QEH Working Paper Series, QEHWPS 99, Oxford: University of Oxford, 2003.

Venugopal, Rajesh. "The Politics of Market Reform at a Time of Civil War: Military Fiscalism in Sri Lanka." Economic and Political Weekly 46, no. 49 (2011): 67-75 http://www.jstor.org/stable/41319460.

Walter, Barbara F. "Conflict Relapse and the Sustainability of Post-conflict Peace." World Development Report Background Papers; 2011. Washington, DC: World Bank, 2010.

Watchdog. "State Facilitated Colonization of Northern Sri Lanka - 2013." Groundviews September 19, 2013.

Webster, Colin, and Sarah Kingston. Anti-Poverty Strategies for the UK Poverty and Crime Review. Centre for Applied Social Research (CeASR) Leeds Metropolitan University, Joseph Rowntree Foundation, May 2014.

Wickramasinghe, Nira. "Sri Lanka in 2013: Post-war Oppressive Stability." Asian Survey 54, no. 1 (2014): 199-205. doi:10.1525/as.2014.54.1.199.

Wijeweera, Albert and Matthew J. Webb. "Military Spending and Economic Growth in Sri Lanka: A Time Series Analysis", Defence and Peace Economics 20, no. 6 (2009): 499-508. doi:10.1080/10242690902868301.

YPF. Nexus between Post War Trauma and Increased Violence. Research Department, 2012. http://www. onetext.org/wp-content/uploads/2013/06/Research-on-the-Nexus-between-the-Post-War-Traumaand-Increased-Violence-in-Sri-Lanka.pdf.

Zunzer, Wolfram. Diaspora Communities and Civil Conflict Transformation. Berghof Occasional Paper No. 26. Berghof Research Centre for Constructive Conflict Management, September, 2004. 